\title{
Textile Bio Processing Using Aloe Gel
}

\section{Amanuel L* and Teferi X}

Department of Textile Engineering, Wollo University - Kombolcha Institute of Technology, Ethiopia, Africa

\begin{abstract}
Biotechnology is a frontier area in science and technology having significant commercial applications in healthcare, agriculture, Textile, process industry and service sectors all over the world. Aloe Vera is in an advantageous plant to harness the potential of biotechnology application in textile pretreatment and coloration due to its property of naturally occurring coloration. Availability and abundance, catalyst chemicals such as amylase and lipase and Sodium ion, the present investigation aims at using aloe gel as bio polymer in pretreatment and coloration of cotton textiles.
\end{abstract}

Keywords: Biotechnology; Textile pretreatment; Coloration and coloration

\section{Introduction}

It is important to note that biotechnology is not just concerned with biology, but it is a truly interdisciplinary subject involving the integration of natural and engineering sciences. Biotechnology is like an enormous "factory" which not only provides other industries with innovative ideas, but also supplies the appropriate knowledge. Now familiar with the application of modern biotechnology in medicine and agriculture: so-called red and green biotechnology. There is less general awareness of the white variety: the use of biotechnology for industrial applications. These are all examples of biotechnology in action, a sector that is constantly growing and expanding into other industrial sectors, a true driving force of interdisciplinary applications. The current trend deals with the potential of aloe Vera gel as biotechnology in the textile industry.

The aloe plant, being a cactus plant, is about $95 \%$ water, with an average $\mathrm{pH}$ of 4.5 . The remaining solid material contains over 75 different ingredients including vitamins, minerals, enzymes, sugars, anthraquinones or phenolic compounds, lignin, saponins, sterols, amino acids and salicylic acid [1].

Several of enzyme biochemical catalysts, such as amylase and lipase, can aid digestion by breaking down fats and sugars. One important enzyme, a carboxy-peptidase, inactivates bradykinins and produces an anti-inflammatory effect. During the inflammatory process, bradykinin produces pain associated with vasodilation and, therefore, its hydrolysis reduces these two components and produces an analgesic effect [2].

As mineral composition Aloe Vera contains Calcium, Manganese, Sodium, Copper, Magnesium, Potassium, Zinc, Chromium and Iron. these minerals are essential for human health care; calcium is essential for proper bone and teeth density, Manganese a component of enzymes necessary for the activation of other enzymes, Sodium ensures that the body fluids do not become too acidic or too alkaline, Copper enables iron to work as oxygen carriers in the red blood cells, Magnesium is used by nerves and muscle membranes to help conduct electrical impulses, Potassium regulates the acidic or alkaline levels of body fluid, Zinc contributes to the metabolism of proteins, carbohydrates and fats, Chromium is necessary for the proper function of insulin, which in turn controls the sugar levels in the blood and Iron controls the transportation of oxygen around the body via the red blood cells [2].

\section{Methods and Materials}

Extraction of aloe gel from aloe vera by hand and machine Extraction by hand

- First, cut Aloe Vera leaf from the plant.

- Washing the Aloe Vera leaf to remove the dirt.

- Massaging the solid gel to Change into liquid gel using our hands.

- Extracting the Aloe gel-using spoon from inner parts of the leaf.

\section{Extraction by machine}

- First, cut Aloe Vera leaf from the plant.

- Washing the Aloe Vera leaf to remove the dirt.

- Feeding the Aloe leaf in between the rollers.

- Tightened the handle to decrease the gap between rollers for maximum extraction.

- Rotating the handle to pass the leaves between the pressing rollers, this extracts the gel.

- The extracted gel will be collected on the pan and then the gel will drop into the container through the outlet $[3,4]$.

\section{Desizing of cotton with aloe gel}

\section{Desizing procedure}

- Take sample of gray fabric according to MLR provided.

- Oven dry (condition) the sample and weigh the dry up sample

- Mark $65 \mathrm{~cm}$ x $65 \mathrm{~cm}$ size on sample for shrinkage test

- Prepare the desizing liquor according to the respective recipe

*Corresponding author: Lami Amanuel, Department of Teaxtile Engineering, Wollo University - Kombolcha Institute of Technology, Ethiopia, Africa, Tel: +251924276531; E-mail: lamiamanuel@gmail.com

Received March 26, 2017; Accepted April 25, 2017; Published April 30, 2017

Citation: Amanuel L, Teferi X (2017) Textile Bio Processing Using Aloe Gel. Ind Eng Manage 6: 213. doi:10.4172/2169-0316.1000213

Copyright: (c) 2017 Amanuel L, et al. This is an open-access article distributed under the terms of the Creative Commons Attribution License, which permits unrestricted use, distribution, and reproduction in any medium, provided the original author and source are credited. 
- Check the $\mathrm{pH}$.

- The fabric sample desized in enzymatic method is washed in hot water $\left(80-90^{\circ} \mathrm{C}\right)$ to gelatinize the starch

- Put the fabric samples in the desizing liquor, and carry out desizing according to the time and temperature specified.

A. Carry out after treatment - rinse with hot water $\left(70-95^{\circ} \mathrm{C}\right)$ and give a cold wash

B. Oven-dry (condition) and weigh the sample

X. Finally level the desized fabric sample (Table 1).

\section{Dyeing of Aloe gel treated cotton}

\section{Reactive dyeing of aloe gel treated cotton fabrics}

Materials/chemicals: Aloe gel treated cotton fabrics, different reactive dyes, sodium carbonate, detergent (standard soap).

Equipments/apparatus: Weighing balance, thermometer, scissors, ruler, stirrers, stoves, measuring cylinders, beakers, and other accessories.

Dyeing recipes: Dichlorotriazinyl (DCT); Monochlorotriazinyl (MCT); Bifunctional (BF) (Table 2).

\section{Dyeing procedure}

- After preparing the dye solution and placing the AG treated fabric sample in dye bath follow the following dyeing cycle given for the different kinds of dyes used in the experiment.

- Start dyeing with the bath containing dye solution and fabricat $30^{\circ} \mathrm{C}$

- Continue dyeing for 45 minutes at $30^{\circ} \mathrm{C}$ and add the soda ash solution

- Continue dyeing for $45-60$ minutes at $30^{\circ} \mathrm{C}$ and carry out washing (Figure 1)

- Start dyeing with the containing dye solution and

- Fabric's sample at $50^{\circ} \mathrm{C}$ for 15 minutes

- Continue dyeing while rising temperature to $80-85^{\circ} \mathrm{C}$

- At the dyeing temperature $80-85^{\circ} \mathrm{C}$ continue dyeing for 10 minutes and add soda ash solution.

- Continue dyeing for 30-60 minutes and carry out washing (Figure 2)

\begin{tabular}{|c|c|}
\hline & $\begin{array}{c}\text { MLR; } \mathrm{PH}=6-7 ; \text { Temp }=70-80^{\circ} \mathrm{C} ; \\
\text { Time }=60 \mathrm{~min}\end{array}$ \\
\hline Chemical used & Conc. $(\mathrm{gpl})$ \\
\hline Aloe gel & $50-60$ \\
\hline Sodium chloride & 5 \\
\hline Non-ionic wetting agent & 1.5 \\
\hline
\end{tabular}

Table 1: Recipe for enzymatic desizing of cotton fabrics.

\begin{tabular}{|c|c|c|c|}
\hline \multirow{2}{*}{ Chemical used } & \multicolumn{3}{|c|}{ MLR 1:10 } \\
\cline { 2 - 4 } & \multicolumn{3}{|c|}{ Type of reactive dyes } \\
\cline { 2 - 4 } & DCT & MCT & BF \\
\hline Reactive dye (\%o.w.f) & 1 & 1 & 1 \\
\hline Sodium carbonate (glp) & 5 & 15 & 15 \\
\hline
\end{tabular}

Table 2: Recipe for dyeing of aloe gel (AG) treated fabric with four different dyes.
- Start dyeing with the bath containing dye solution and fabrics sample at $30^{\circ} \mathrm{C}$

- After 30 minutes add predissolved alkali and raise temperature for 30 minute to $60^{\circ} \mathrm{C}$

- Continue dyeing at $60^{\circ} \mathrm{C}$ for 30-60 minutes

- Lastly carry out rinsing (Figures 3 and 4 )

- Start dyeing with the bath containing dye solution and fabrics sample at $30^{\circ} \mathrm{C}$

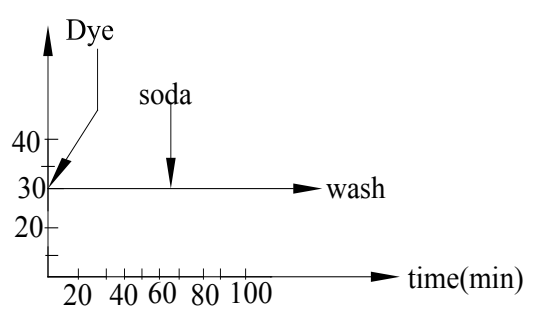

Figure 1: Typical dyeing cycle for dichlorotriazinyl dye exhaustion method.

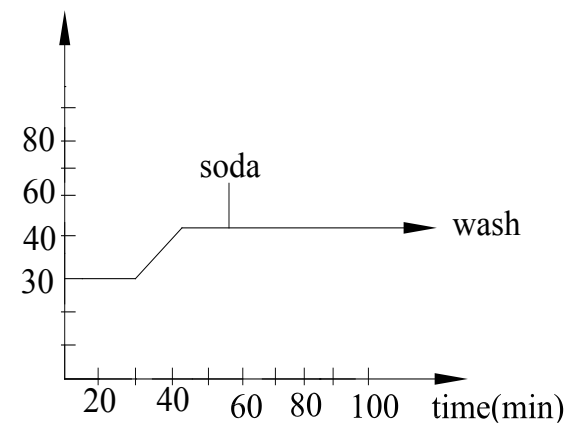

Figure 2: Typical dyeing cycle for Dichlorotriazinyl dye exhaustion method.

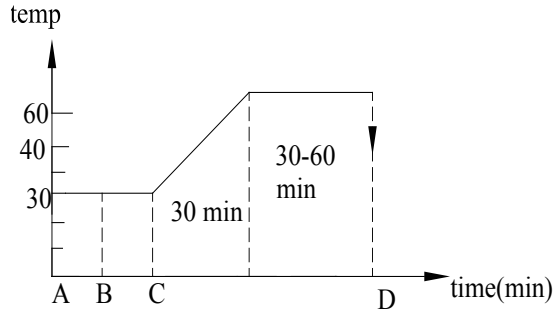

Figure 3: Typical dyeing cycle for vinyl sulphone: exhaustion method.

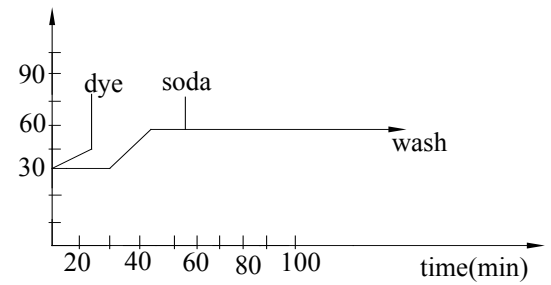

Figure 4: Typical dyeing cycle for bi functional reactive dye: Exhaustion method. 
- Continue dyeing for 20 minutes and raise temperature to 60 $65^{\circ} \mathrm{C}$ for 20 minutes

- After 15 minutes add soda ash solution and continue dyeing at $60-65^{\circ} \mathrm{C}$

- Continue dyeing for 60 minutes and carryout washing [5-7].

Notes: as per requirement soaping can be carried out using $5 \mathrm{gpl}$ standard soap at boiling temperature for 20 minutes. then final rinsing is carried out by washing the fabrics with hot water $\left(50-60^{\circ} \mathrm{C}\right)$ for $5 \mathrm{~min}$ and with cold water and cold water for 5 minutes.

\section{Printing of cotton with aloe gel thickener}

\section{Pigment printing}

Materials/chemicals/equipments/apparatus: Materials/chemicals bleached fabrics, pigments, aloe gel, cross linking agent, urea, ammonia liquor, ammonium sulphates, and other auxiliaries.

Equipments/apparatus: Weighing balance screens screen printing table, squeegee, and scissors, rulers, ovens, stirrers, stoves, measuring cylindering, pressure cooker, beakers, and other accessories.

\section{Pigment printing recipe and procedure}

Pigment printing paste preparation: Prepare the paste for pigment printing by mixing the different chemicals according to the scheme shown below (Table 3).

Fabric to print

Print Paste preparation

$\downarrow$

Printing (application of print)

$\downarrow$

Drying

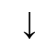

Fixation (curing@ $150^{\circ} \mathrm{C}$ for $5 \mathrm{~min}$ )

After treatment [washing-soaping-washing-drying]

$$
\downarrow
$$

\section{Printed fabric}

Determination of protein content present in the aloe gel by using UV spectrophotometer: The amount of protein present in some natural resource is very crucial to study and to understand the end uses of the material. In case of our study the amount of protein present extracted aloe gel is determined by using UV spectrophotometer, which is operated like normal desktop computer and all its operation is automatic.

It is calibrated by using distilled water or $100 \%$ pure ethyl acetate because the absorption and transmittance of water and ethyl acetate is 0 and $100 \%$ respectively. When it is calibrated all the calibration values become zero and after that the sample is inserted with transparent cubet (equipment used to insert solution material into the machine. At last, the machine is connected to printing machine and all the data has done is printed out with graph of wavelength versus concentration [8-10].
Determination of antimicrobial activity by using agar plate method: The efficiency of aloe Vera on inhibition or killing of disease causing microorganisms is studied by aloe Vera pre-treated fabrics in three different concentrations such as the ratio aloe gel: water $80: 20,60: 40$ and $100 \%$ pure aloe gel treated fabric is tested on nine different plates. The plates rare prepared by using agar nutrition in sterilized plate at temperature of $105^{\circ} \mathrm{C}$ because at this temperature all microorganisms should be died, after that, the agar nutrient is mixed with warm distilled water and shacked as much as possible. When all necessary steps be taken out then the microorganism E. coli (gram negative) is added on nine independently prepared plates, from that three plates for $100 \%$ (one plat only gel, second is for treated fabric and gel and the third is only for treated fabric) and the same is true for $60 \%$ and $80 \%$ aloe gel treated and prepared sample is kept in incubation for 48 hours. For gel we used circularly cut filter paper and the dimension the inhibition zone is measured [11-16].

\section{Results and Discussion}

\section{Test results}

Determination of Antimicrobial effect of aloe gel treated fabrics against E. coli by plate method (Figure 5)

Determination of Protein content present in the Aloe gel by using UV spectrophotometer by wavelength $\lambda$ ( $\mathrm{x}$-axis) versus absorption graph (y-axis) (Figure 6).

\section{Usage of aloe gel instead of synthetic thickener in reactive and pigment printing}

Aloe Vera has thick succulent water-soluble gel, which contains more amount of polysaccharide especially, Polysaccharides: glucomannans/polymannose this sugar is thick in nature and its thickness is used as thickener in reactive and pigment printing. The main advantage of using aloe gel rather than synthetic thickener is:

\begin{tabular}{|c|c|}
\hline & Concentrations (\%) \\
\hline Pigment & Y \\
\hline Aloe gel (natural thickener) & $30-40$ \\
\hline Binder (gpl) & 2 \\
\hline Urea (gpl) & 2 \\
\hline Cross linking agent & 2 \\
\hline Ammonium sulphates & 1 \\
\hline Ammonia liquor & 1 \\
\hline
\end{tabular}

Table 3: Recipe for pigment printing

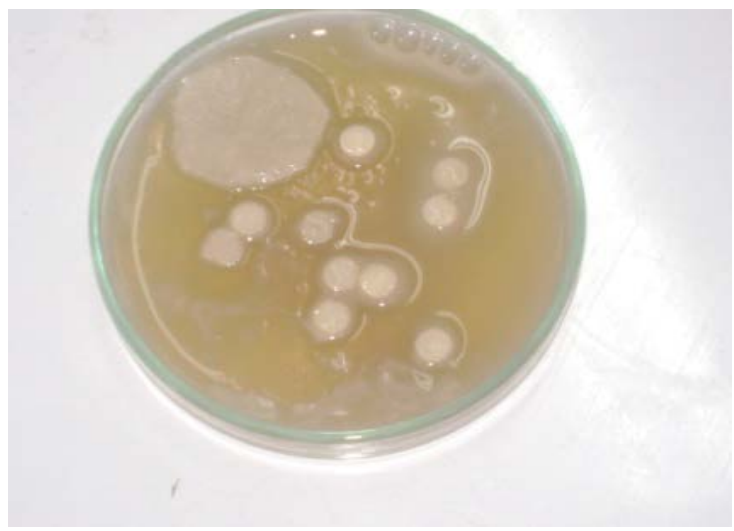

Figure 5: Agar plate test sample. 
The printed sample has deep saturated hue that means it is possible to get real depth of the wanted color,

It has no environmental effect (eco-friendly),

Economically cheap because everyone can cultivate and can use it,

For preparing the paste easy, simple and it consumes minimum time,

Its wash fastness is the same to synthetic thickeners.

\section{Effect of sodium ion present in aloe gel on low salt reactive dyed cotton fabrics}

Since aloe, gel contains many compounds inside like enzymes, amino acids and elements like magnesium, calcium sodium and other essential compounds and elements. From these elements, we tried to use the sodium ion for reactive dyeing without addition of sodium chloride. The fabric pre-treated cotton fabrics dyed with null salt and we got different depth of shade depending on concentration aloe gel the fabrics pre-treated. in our test the fabrics treated with $100 \%$ aloe gel have good and higher shade depth, $80 \%$ aloe gel treated fabrics has medium and the $60 \%$ aloe gel treated fabrics have lower shade depth. Because when the concentration aloe gel is increase the amount of sodium ion inside the aloe gel is directly increases and the dye bath exhaustion so the dye uptake of the fabrics is higher as shown above the results.

When we come to the fabric, properties as if wash fastness, tearing strength, drapiblty is not damaged even the treatment give good texture, smoothness, and medical applications like bandage to wound.

\section{Antimicrobial activity of aloe gel treated sample (agar diffusion test)}

Figure shows the result of Agar Diffusion Test for antimicrobial effectiveness against standard test cultures viz., E. coli (gram negative). The zone of bacterial inhibition is indicated by a halo around the specimen. It is apparent that the activity of aloe gel treated samples is high against $E$. coli. It is attributed that bacterial inhibition is due to the slow release of active substances from the fabric surface. The anthraquinone present in the aloe absorb the fatty acids, which make the fabric free from microbe profilation.

\section{Effect of enzymes present in aloe gel in cotton desizing}

Some of the most important enzymes in Aloe Vera are Peroxidase, Aliiase, Catalase, Lipase, Cellulase, Carboxypeptidase, Amylase and Alkaline Phosphatase. These enzymes have active centres, which are the points where substrate molecule can join. Just as a particular key fits into a lock, a particular substrate molecule fits into the active site of the enzyme. The substrate forms a complex with the enzyme. Later the substrate molecule is converted into the product and the enzyme itself is regenerated (Figure 7).

The process continues until the enzyme is poisoned by a chemical bogie or inactivated by extremes of temperature, $\mathrm{pH}$ or by other negative conditions in the processing environment (Figure 8).

\section{Protein concentration present in extracted aloe gel}

The test result has clearly indicated that the absorbency wave length of aloe gel at $200 \mathrm{~nm} 2.957$ and $290 \mathrm{~nm} 2.674$ but the wave length is constant in between $205 \mathrm{~nm}$ and $280 \mathrm{~nm}$. It can be strongly believe that most of the protein has strong and peak absorbency at the above mentioned $\mathrm{nm}$. Hence, the protein present in the extracted gel is very pure without any variation in the frequency curve.

\section{Conclusion}

Irrespective of color and percentage shade, dye uptake of reactive dyed by cotton fabric highly depends on the concentration of aloe gel in padding solution of pre-treatment for dyeing. The extent of improvement in dye uptake depends on concentration of sodium ion as well as duration of treatment. When the fabric is treated with higher concentration of aloe gel, the dye shade depth can be improved. Higher the concentration of sodium ion and longer the duration of the treatment better will be dye uptake. The aloe gel treated fabric was exhibited high desizing efficiency. This is due to key -Lock mechanism of enzymes present in the aloe gel. When we compare the desizing efficiency of synthetic enzyme and aloe gel enzyme (natural enzyme amylase) the weight lose is greater that means the weight loss in synthetic enzyme desizing is $7.9 \%$ and in aloe gel case it is $11.02 \%$ so it has good desizing efficiency but aloe gel desizing have side effect of coloring salt.

Remedies: it can be improved by usual scouring method.

Because Aloe Vera has six antiseptic agents (Anthraquinone, sulphates, lupeol, salicylic acid, cinnamic acid, urea nitrogen and phenol) which act as a team to provide antimicrobial activity thus eliminating many internal and external infections. From our lab result aloe gel treated fabric has very high inhibition against $E$. coli microorganism.

The qualitative amount of protein presenting in aloe gel is from 2.5-3 gram in one litter of aloe gel and this have good promising for

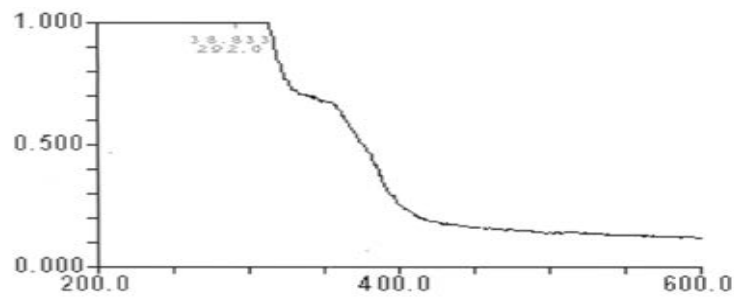

Figure 6: UV spectrophotometer.

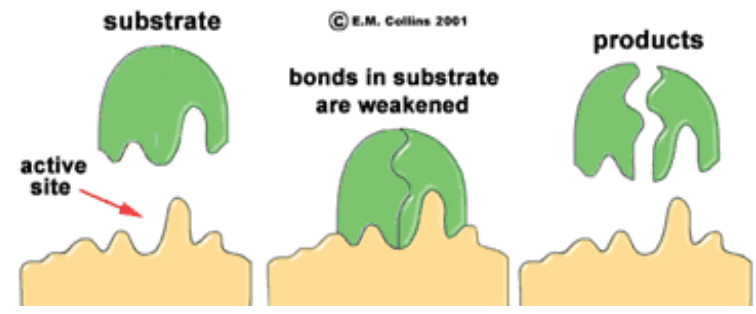

Figure 7: Lock \& Key model of enzyme specificity.

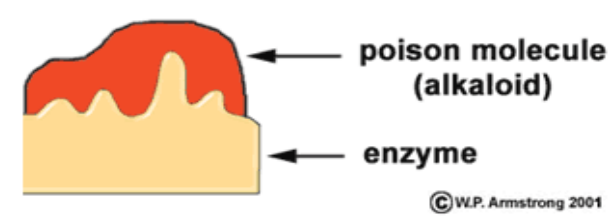

Figure 8: Active site of enzyme blocked by poison molecule. 
production of glycoprotein which is responsible for white blood cell production. And also the protein present in the aloe gel is extremely pure and free from fertilizer. The test results of aloe gel printed fabrics have strongly showed that aloe gel can be used as natural thickener in place of synthetic thickener. When we use aloe gel the color depth is much higher than synthetic printed fabric. This is because of the nature of aloe gel is colorless when it is pure. But the synthetic thickener is $s$ white in color influences the color depth. In addition to our work further research work should be suggested to find out the miracles nature and application of aloe Vera.

\section{References}

1. Surjushe A, Vasani R, Saple DG (2008) Aloe vera: A short review. Indian J Dermatol 53: 163-166.

2. S Senthilnathan (2012) A case study on safety and efficacy of aloe vera extract in primary dyslipidemic patients. Journal of Innovative Research and Solutions (JIRAS) 1: 73-83.

3. Klaus Schatz (2001) All Round Answer to Problem Microbes. International Dyer, pp: 17-19

4. Yang Y, Corcoran L, Vorlicek K, Li S (2000) Durability of Some Antibacterial Treatments. Textile Chemist and Colorist and American Dyestuff Reporter 32: 44-49.

5. Binghamton NY (1993) Third Edition: Pharmaceutical Products Press.

6. Odes HS, Madar ZA (1991) double-blind trial of a celandin, aloevera and psyllium laxative 5.preparation in adult patients with constipation. Digestion 49: 65-71.

7. Brusick D, Mengs U (1997) Assessment of the genotoxic risk from laxative senna products. Environmental and Molecular Mutagenesis 29: 1-9.

8. Grindlay D, Reynolds (1986) The Aloe vera phenomenon: A review of the properties and modern uses of the leaf parenchyma gel. Journal of Ethnopharmacology 16: 117-151.

9. Davis RH, Leitner MG, Russo JM, Byrne ME (1989) Wound healing. Oral and topical activity of aloe vera. Journal of the American Podiatric Medical Association 79: 559-562.

10. Hecht A (1981) The overselling of aloe vera. FDA Consumer 15: 26-29.

11. Ghannam N, Kingston M, Al-Meshaal IA, Tariq M, Parman NS, et al. (1986) The antidiabetic activity of aloes: preliminary clinical and experimental observations. Horm Res 24: 288-294.

12. Al-Awadi F, Fatania H, Shamte $U$ (1991) The effect of a plants mixture extract on liver gluconeogenesis in streptozotocin induced diabetic rats. Diabetes Res 18: 163-168.

13. Byrne C (1995) Textile Institutes Dyeing and finishing Group conference, Nottingham.

14. Rashush D (1998) Asian Textile Journal, Jan' 2002. Ethers JN and Annis PA.Textile enzyme viz., a developing technology. A.D.R 5: 18-23.

15. Dyed- Rep (2000) Enzyme Technical Association, Washington, 'Safe handling of enzymes. Text Chem. Col and Am 32: 26-7.

16. Bohringer A, Jurg R (2002) Biotechnology. Processes and products. I.T.B 48 6-19. 